https://www.journal-imab-bg.org

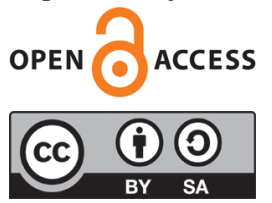

Original article

\title{
MONITORING OF LEGIONELLA SPP. IN THE WA- TERWAYS OF MEDICAL INSTITUTIONS
}

\author{
Velina Stoeva ${ }^{1}$, Ani Kevorkyan ${ }^{1}$, Iskra Tomova ${ }^{2}$, Yordanka Stoilova ${ }^{1}$ \\ 1) Department of Epidemiology and DM, Faculty of Public Health, Medical \\ University, Plovdiv, Bulgaria. \\ 2) NRL Especially dangerous bacterial infections, National Center of Infec- \\ tious and Parasitic Diseases, Sofia, Bulgaria.
}

\begin{abstract}
:
Purpose: To monitor the presence of legionella bacteria in the water supply system of medical institutions in order to optimize the recommendations for the quality of water used for treatment.

Materials and methods: Two cross-sectional epidemiological studies were performed to prove representatives of Legionella spp. in water samples from medical and dental equipment and water from the water supply network in medical institutions (MI) in Plovdiv. During the first period of time (March 2013 - March 2015), a total of 97 samples were taken and 24 samples during the second period (July-August 2019) in two consecutive visits. The following were examined: Faculty of Dental Medicine (FDM), Surgical Complex (SC) of the University Hospital "St. Georgi" and individual dental practices (IDP). Water samples were tested at NCIPD-Sofia.

Results: In the period 2013-2015, the presence of legionella bacteria was found in $33(34.02 \%)$ of the SC samples, in 1 out of 10 samples in IDP, and there were none detected in FDM. Non-compliances with requirements of hot water temperature, type of water used when working with devices generating a fine water aerosol have been found. Five years later, only 1 positive sample of SC was proved, in which the water supply network was rehabilitated in the interval between the two surveys.

Conclusion: For the purposes of good medical and dental practice, it is necessary to conduct periodic monitoring of the "legional landscape" and the microbiological status of the water used for treatment.
\end{abstract} antibodies,

Keywords: dentistry, Legionellosis, water supply,

\section{INTRODUCTION:}

Legionellosis is a relatively new (1976) acute infectious disease with two forms of manifestation - Legionnaires' disease with severe pneumonia and Pontiac fever with flu-like symptoms [1, 2, 3, 4]. Mortality in the severe forms and in patients who have not received adequate treatment is $15-20 \%$ and reaches $50 \%$ in immunocompromised patients[1, 2].

The causative agents are Gram-negative bacteria of the genus Legionella. A person becomes infected by inha- lation of an aqueous aerosol generated by natural and especially artificial water systems, which are easily colonized by legionella bacteria. This, combined with the stagnation of water in the many medical and dental devices that are used during work, leads to a real risk of nosocomial infections associated with Legionella. Any water system that operates in the temperature range between $25-50^{\circ} \mathrm{C}$ and can create an aqueous aerosol has the potential to cause disease $[1,2,3,4,5,6,7]$. It is of paramount importance to protect the water as a main reservoir and factor for infection transmission. In this regard, additional preventive measures should be taken in medical institutions to ensure patient care according to good medical and dental practice: tap water should not be used to maintain respiratory therapy devices (humidifiers, dispensers, etc.). For washing and filling their tanks, only sterile water should be used $[1,7-14]$. The aim of our survey is to monitor the water supply system of medical institutions to assess the "Legionella landscape" and make recommendations for optimizing the quality of water used for treatment.

\section{MATERIALS AND METHODS:}

Two ross-sectional studies were performed to determine the presence of Legionella spp. in water samples from healthcare facilities related to dental and medical practice for the period March 2013-March 2014 (a total of 97 water samples) and July-August 2019 (a total of 24 water samples). Samples were taken from: Faculty of Dental Medicine (FDM), MU - Plovdiv; Surgical complex (SC), University Hospital "St. George", Plovdiv, Clinic of Oral and Maxillofacial Surgery (COMS), University Hospital "St. George", Plovdiv; individual dental practices (IDP) in Plovdiv; Dental office in Multiprofile Hospital Plovdiv. The number of samplings was 5 in the first period and 2 in the second. They were taken from associated sources of the water system: showers, washbasins, therapeutic baths, etc., as well as from central and endpoints on the floor of the COMS. In the second period, there were also samples taken from new sites (the clinics of Rheumatology, Hematology and Hematopoetic Stem Transplantation Department, Cardiology and Neurosurgery of St. George University Hospital). Each sample was collected in a volume of $500 \mathrm{ml}$ of water, stored and transported in a cooler bag and inoculated on specific media for Legionella BCYE agar - buff- 
ered charcoal-yeast extract agar (according to the requirements of the Guidelines for the management of Legionnaires' disease from 2003). Water samples were tested in the NRL "Especially dangerous bacterial infections" at NCIPD-Sofia in accordance with ISO 11731-1: 1998 Water quality - Detection and enumeration of Legionella. For all tests, $\mathrm{p}<0.05$ was considered a statistically significant difference. Professional statistical processing software SPSS version 19.0 is used for data analysis.

\section{RESULTS:}

In the period 2013-2015 (first period) of the studied 97 waterways in $33(34.02 \%)$ L. pneumophila was detected, and the samples were taken at intervals of 3 months (table 1). Only one sample of those taken in August 2019 showed growth of L. pneumophila (table 1).

Table 1. Distribution of water samples tested for the presence of Legionella spp., According to the order of sampling in 2013-2015 and in 2019.

\begin{tabular}{|l|c|c|c|c|}
\hline \multirow{2}{*}{ Sampling } & \multicolumn{2}{|c|}{$\begin{array}{c}\text { First period } \\
\text { (March 2013- } \\
\text { March 2015) }\end{array}$} & \multicolumn{2}{c|}{$\begin{array}{c}\text { Second period } \\
\text { (July-August 2019) }\end{array}$} \\
\cline { 2 - 5 } & Samples & $\begin{array}{c}\text { Positive } \\
\text { samples } \\
\text { n (\%) }\end{array}$ & $\begin{array}{c}\text { Samples } \\
\text { n }\end{array}$ & $\begin{array}{c}\text { Positive } \\
\text { samples } \\
\text { n(\%) }\end{array}$ \\
\hline First & 17 & $6(35.3)$ & 12 & 0 \\
\hline Second & 20 & $7(35)$ & 12 & $1(8.33)$ \\
\hline Third & 18 & $5(27.8)$ & - & - \\
\hline Fourth & 18 & $6(33.33)$ & - & - \\
\hline Fifth & 24 & $9(37.5)$ & - & - \\
\hline Overall & $\mathbf{9 7}$ & $\mathbf{3 3 ( 3 4 . 0 2 )}$ & $\mathbf{2 4}$ & $\mathbf{1 ( 8 . 3 3 )}$ \\
\hline
\end{tabular}

\section{3-2015}

In the course of the sampling during the first period in the Surgical complex of St. George University Hospital, significant problems were identified:

1. The temperature of the hot water was in the range $17.9^{\circ} \mathrm{C}-44.0^{\circ} \mathrm{C}$, with an average temperature of 30.85 $43.25^{\circ} \mathrm{C}$.

2. The temperature of the cold water - varied in the range $15.6^{\circ} \mathrm{C}-19^{\circ} \mathrm{C}$.

3 . The water supply was heterogeneous (central or autonomous). The autonomous one was with distilled water at varying room temperature.

The analysis of the water parameters in the Faculty of Dental Medicine was similar to those in the Surgical complex, however, no Legionella spp were isolated there. The collected information about the water supply system in the two healthcare facilities showed that in the FDM, the water system network was relatively new - in operation since 2006. The water supply system of the SC was built in 1965 and put into operation in 1987. At the time of the first sampling, a major replacement of the system was not performed, but only partially due to accidents over the years. Legionella spp. were found only in one of the studied individual dental offices in Plovdiv.

\section{9}

The study revealed improvements in the water system in the SC of St. George University Hospital, such as:

Cold water: Partial replacement of the water supply networks has been carried out, mainly where there have been accidents (mainly for return waters). The entire hydrophore system has been replaced, and new modern pumps have been installed. The pipes and taps have been partially replaced, and insulation has been installed.

Hot water: The water softening system and hot water pipes were replaced in 2018. Water with a temperature of $60{ }^{\circ} \mathrm{C}$ to $70{ }^{\circ} \mathrm{C}$ was supplied from the plant everywhere, and water with a temperature of approximately $30{ }^{\circ} \mathrm{C}$ was being returned, depending on the consumption.

\section{DISCUSSION:}

The presence of Legionella spp. in about 1/3 of the water samples during the first period requires increasing the attention of health professionals and the management staff of the medical institution. The temperature of the hot water measured by us in the range $17.9^{\circ} \mathrm{C}-44.0^{\circ} \mathrm{C}$ does not meet the requirements, moreover, that the optimal temperature for the replication of Legionella is between $25^{\circ}-45^{\circ} \mathrm{C}$ [1]. According to the requirements of the European Guidelines for Control and Prevention of Travel Associated Legionnaires' Disease, in 2011, the temperature of hot water must be above $60^{\circ} \mathrm{C}$ and of cold water below $20^{\circ} \mathrm{C}$ in order to prevent the development and replication of Legionella [10].

All this, as well as the lack of a program for prevention of legionnaires' infections in the studied sites, which were lacking in other hospitals in the country as well, are prerequisites for colonization of water transmission systems with the potential for nosocomial legionnaires' infections.

In addition, a sero-epidemiological study conducted by us during this period found the presence of anti- $L$. pneumophila antibodies among medical and dental staff in a statistically significant amount compared to the control group $(40.91 \% \pm 6.05$ vs $7.78 \% \pm 2.82, \mathrm{p}<0.05)[15]$, which is indirect evidence to support the likelihood of transmission of Legionella bacteria in hospitals.

The results of the water samples are indicative of the need for optimization and increased control of the water supply system, as well as the use of only sterile water for treatment, use of personal protective equipment when working with devices generating fine water aerosol, as gaps were identified. It is accepted that the number of samples and the future actions resulting from the results are determined individually for each water distribution system (building). For medical and healthcare facilities, not only Legionella pneumophila $\mathrm{Sg} 1$ is important, but also $\mathrm{Sg}$ 1, 3, 6, 10 and 8 [1].

Taking into account the recommendations of the experts in the field in our country and the regular inspections of the water quality carried out in other countries, in 2019, we again monitored the waterways of the same medical in- 
stitutions. The obtained good results are related to the measures taken for repair and replacement of the water supply system in the medical institution.

Based on the experience of Bulgarian and foreign experts, we prepared the following recommendations $[16,17]$ : flushing waterways with emphasis on disinfection, increasing the knowledge and elimination of factors for the spread of L. pneumophila, warming and softening of water, testing the waterways of the dental unit for $L$. pneumophila.

Authors $[18,19]$ unite and point the solution to the problem in two directions:

1. Non-chemical influence on the waterways of the dental unit by improvement in the engineering and redesign: the length of the stagnant section can be reduced by redesigning the unit to maintain the water flow continuously (the water to flow), 0.2 micrometers membrane filters are used for filtration when we want to reduce the need for chemical intervention, flushing water for a few minutes before the first patient and for 20-30 seconds between patients to reduce the number of bacteria in the waterways. However, the reduction is only temporary, as the micro-organisms will multiply again in a very short time [10]. An alternative strategy may be to clean the waterways at the end of the day and dry them at night to reduce the biofilm formation [10], to check the waterways of the dental unit for biofilm formation, to use disinfectants to reduce the biofilm formed [12].

2. Chemical treatment of the waterways of the dental unit by using a combination of chemical agents for removal and destruction of the biofilm. Products usually contain chemical ingredients such as sodium hypochlorite, chlorine dioxide, peroxides, citric acid.

Of interest are the safety measures for water used in medical and dental practices in other countries. In England, this issue is regulated by specialized guidelines [20] and regulations [21], which specify the strict requirements for all landlords and employers, as well as ensuring water safety and control of legionella status. An assessment must be made at the workplace of all buildings where there is a foreseeable risk of exposure to bacteria of the genus Legionella. Annual water sampling is recommended at most retail outlets. It is a legal obligation to carry out a legionella risk assessment and water hygiene in order to identify and assess the risk.

The use of disinfectants and temperature parameters should be regularly monitored through a water quality management program [22]. According to the CDC's recommendations, routine prospective environmental water samples for Legionella, rather than in the context of an epidemiological study of outbreaks, are one way to validate the effectiveness of a water management program [10]. The safe level of Legionella in water distribution systems is not known, as cases of the disease are associated with even very low levels of the pathogen in them. If legionnaires' bacteria are detected during the routine collection of environmental water samples (in the absence of human disease), the CDC proposes to investigate possible causes of growth.

The temperature control or rinsing with an appropriate water system detergent may be sufficient, but ad- ditional measures may be required if a persistent trend in the presence of these bacteria is observed (e.g. persistent positive samples from the same site, positive samples at a central point of distribution, positive samples at multiple points on the network, diversity of legionellae species detected). [10]

A team from Sweden, after studying for a period of 10 years (1991-2000) nosocomial outbreaks of Legionnaires' disease in a regional hospital with 450 beds, concludes that control of the disease is possible by maintaining the temperature of circulating hot water in the hospital above $55^{\circ} \mathrm{C}$, as the sole control measure, together with close clinical monitoring [23]. During the period, all cases of nosocomial pneumonia were clinically monitored and tested for Legionella pneumophila serogroup 1 serologically or by detection of urinary antigen. Water samples from peripheral taps from the water supply network were cultured for Legionella spp. two times a year. They detected $L$. pneumophila serogroup1 infection in $1.1 \%$ of patients treated for nosocomial pneumonia and in $12 \%$ of water samples during the study period.

In Bulgaria, the requirements governing the quality and safety of water, including that used in the treatment of patients, both in medical and dental practices, are laid down in Methodological Instruction No.3 of 25.11.2003 of the Ministry of Health for the management of Legionellosis. [1], but in reality, their practical implementation is not controlled by the Regional Health Inspectorates.

The results of our survey among medical and dental staff [24] concerning the clinics and epidemiology of Legionnaires' disease showed that they do not know and do not follow the basic measures for prevention and control. According to the recommendations of the National Reference Laboratory "Especially Dangerous Bacterial Infections" at the National Center for Infectious and Parasitic Diseases in Sofia, when monitoring water quality, many other bacteria that multiply and are transmitted by water should be taken into account and monitored. This has been confirmed by other studies [25], with the microbiological diversity found in water from dental unit tanks: the predominant species are Gram-negative rods from the families of Burkholderiaceae, Pseudomonadaceae, Ralstoniaceae, Sphingomonadaceae, Ralstonia pickettii, as well as Grampositive rods such as Brevibacterium and Actinomyces spp.

\section{CONCLUSION}

The partially replaced cold water supply network, the timely response to accidents, on the one hand, as well as the completely replaced hot water pipes and the continuous availability of hot water with a sufficiently high temperature, led to a much better result in the second sampling compared to the baseline results obtained 5 years ago. For the purposes of good medical and dental practice, it is necessary to conduct periodic monitoring of the "Legionella landscape" and the microbiological status of the water used in the treatment, determined by experts on the problem specifically for each hospital dental office and others. 


\section{REFERENCES:}

1. [Methodical guide No.3 25.11.2003 for the treatment of legionellosis.] Ministry of Health, Bulgaria. [in Bulgarian]

2. Ricci ML, Fontana S, Pinci F, Fiumana E, Pedna MF, Farolfi P, et al. Pneumonia associated with a dental unit waterline. Lancet. 2012 Feb 18; 379(9816):684. [PubMed]

3. Kohli A, Puttaiah R. Dental infection control and occupational safety for oral health professionals in India 2007. [Internet]

4. Costerton JW, Cheng KJ, Geesey GG, Ladd TI, Nickel JC, Dasgupta M, et al. Bacterial biofilms in nature and disease. Annu Rev Microbiol. 1987; 41:435-64. [PubMed]

5. Mackowiak PA. The normal microbial flora. $N$ Engl J Med. 1982 Jul 8;307(2):83-93. [PubMed]

6. Marsh PD, Lewis MAO, Rogers H, Williams D, Wilson M. Marsh and Martin's Oral Microbiology. 6th edition. Elsevier. 2016. [Internet]

7. Stypulkowska-Misiurewicz H, Czerwiñski M. Legionellosis in Poland in 2016. Przegl Epidemiol. 2018; 72(2):143-147. [PubMed]

8. Robesyn E, Payne Hallström L, Young J, de Jong B. Timeliness of travel-associated Legionnaires' disease surveillance. Cent Eur J Public Health. 2018 Jun 30;26(2):154-155. [PubMed]

9. Herwaldt LA, Marra AR. Legionella: a reemerging pathogen. Curr Opin Infect Dis. 2018 Aug;31(4): 325-333. [PubMed]

10. Kohn WG, Collins AS, Cleveland JL, Harte JA, Eklund KJ, Malvitz DM. Guidelines for infection control in dental health-care settings-2003. MMWR Recomm Rep. 2003 Dec 19; 52(RR-17):1-61. [PubMed]

11. Meiller TF, Depaola LG, Kelley
JI, Baqui AA, Turng BF, Falkler WA. Dental unit waterlines: biofilms, disinfection and recurrence. J Am Dent Assoc. 1999 Jan;130(1):65-72 [PubMed]

12. Orkis LT, Harrison LH, Mertz KJ, Brooks MM, Bibby KJ, Stout JE. Environmental sources of communityacquired legionnaires' disease: A review. Int J Hyg Environ Health. 2018 Jun;221(5):764-774. [PubMed]

13. Zanetti F, Stampi S, De Luca G, Fateh-Moghadam P, Antonietta M, Sabattini B, et al. Water characteristics associated with the occurrence of Legionella pneumophila in dental units. Eur J Oral Sci. 2000 Feb; 108(1):22-8. [PubMed]

14. Decontamination Health Technical Memorandum 01-05: Decontamination in primary care dental practices. Second edition. Department of health. 2013. [Internet]

15. Kevorkyan A, Tomova I, Raycheva R, Stoeva V, Stoilova Y, Lalabonova $\mathrm{H}$, et al. Legionella pneumophila antibodies in serum samples from medical and dental personnel: a seroepidemiological survey. Biotechnol Biotechnol Equip. 2017; 31(3):588-593. [Crossref ]

16. Stoeva V. [Infections in dental practice: prevention and control.] [dissertation]. Plovdiv (Bulgaria) Medical University of Plovdiv. 2017. 197p. [in Bulgarian]

17. Ma'ayeh SY, Al-Hiyasat AS, Hindiyeh MY, Khader YS. Legionella pneumophila contamination of a dental unit water line system in a dental teaching centre. Int J Dent Hyg. 2008 Feb;6(1):48-55. [PubMed]

18. Daeschel MA, McGuire J. Interrelationships between protein surface adsorption and bacterial adhesion.
Biotechnol Genet Eng Rev. 1998; 15:413-38. [PubMed]

19. Farmer JJ 3rd, Davis BR, Hickman-Brenner FW, McWhorter A, Huntley-Carter GP, Asbury MA, et al. Biochemical identification of new species and biogroups of Enterobacteriaceae isolated from clinical specimens. J Clin Microbiol. 1985 Jan;21(1): 46-76. [PubMed]

20. Legionnaires' disease. The control of legionella bacteria in water systems. Approved Code of Practice and guidance on regulations. L8 (4th edition). HSE. 2013. [Internet]

21. Health and Safety at Work etc. Act 1974. UK Public General Acts. 1974 c. 37. [Internet]

22. Davies S. Navigating the waterline regulations. BDJ Team. 2018 Apr 3;5:31-32. [Crossref]

23. Darelid J, Löfgren S, Malmvall B-E. Control of nosocomial Legionnaires' disease by keeping the circulating hot water temperature above $55^{\circ} \mathrm{C}$ : experience from a 10 -year surveillance programme in a district general hospital. J Hosp Infect. 2002 Mar;50(3):2139. [PubMed]

24. Stoeva V, Kevorkyan A, Raycheva R, Tomova I, Atanasovski A, Kondeva V, et al. [Assessment of the knowledge of medical and dental specialists regarding the clinical and epidemiological characteristics of Legionnaires' disease] [in Bulgarian] Science and Youth. Collection of scientific reports from the competition session 2016. MU-Plovdiv. 2016; pp.373-380. [Internet]

25. Szymañska J, Sitkowska J. Bacterial contamination of dental unit waterlines. Environ Monit Assess. 2013 May;185(5):3603-11. [PubMed]

Please cite this article as: Stoeva V, Kevorkyan A, Tomova I, Stoilova Y. Monitoring of Legionella spp. in the waterways of medical institutions. J of IMAB. 2022 Jan-Mar;28(1):4190-4193. DOI: https://doi.org/10.5272/jimab.2022281.4190

Address for correspondence:

Dr Velina Stoeva, PhD

Department of Epidemiology and DM, Faculty of Public-Health, Medical University - Plovdiv, 15 A, Vasil Aprilov Str., Plovdiv, Bulgaria

E-mail: velina1111@mail.bg 